\title{
Sexual health care of two generations of men: continuities and volatilities of scripts and habitus
}

Bruno José Barcellos Fontanella ${ }^{1}$

Romeu Gomes ${ }^{2}$

${ }^{1}$ Departamento de

Medicina, Centro de

Ciências Biológicas e da Saúde, Universidade Federal de São Carlos. Rod. Washington Luís km 235, SP-310. 13565-905 São Carlos SP Brasil. bruno. fontanella@gmail.com ${ }^{2}$ Departamento de Pesquisa, Instituto Nacional de Saúde da Mulher, da Criança e do Adolescente Fernandes Figueira, Fiocruz.

\begin{abstract}
To acquire in-depth understanding of meanings attributed by young men to sexual health care, the similarities and asymmetries present in a corpus of 60 reports of men from two different generations were analyzed regarding this type of care. A process of in-depth hermeneutics was undertaken under the theoretical sociological perspectives of sexual scripts, male habitus and generation. Fifteen analytical categories were grouped together into the three dimensions of sexual scripts (intra-psychic, interpersonal and cultural). Some findings indicate the presence of provisions which were not enduring and have not been transposed to the next generation. However, striking cultural similarities or habitus around male sexuality were also found in the two different socio-historical contexts, allowing for an interpretation on the as yet inconstant use of condoms among the young.
\end{abstract}

Key words Health behavior, Sexuality, Self-care, Masculinity 


\section{Introduction}

In this article we report on one of the analytical-interpretive products of an investigation whose general objective was to understand the meanings attributed to their sexual health care by young men. We present the results and conclusions about some specific objectives that were formulated to answer the question: what are the similarities and asymmetries between the significance attributed to this kind of care by men pertaining to two different generations?

This question refers to the uncertainty about how much the same male habitus persists or the degree of durability of this system of dispositions in the course of two successive generations. We believe that the answer to the question would also be enhanced by the concept of generation and the theory of sexual labeling, and have commented on this below.

Habitus. The idea of habitus, which was developed by Pierre Bourdieu, is part of a long tradition of philosophical texts that date back to Aristotle's concept of hexis. It is linked directly to the concept of socialization, but also refers to behaviors, actions and conduct of individuals in day-to-day living practices. The concept lies in an area which is intermediate between social systems and the psyche, contributing to the organization and expression of both instances, reconciling "the apparent opposition between external reality and individual realities"1 and contrasting with individual-society dualism ${ }^{2}$. Bourdieu ${ }^{3}$ made reference to certain indicators of habitus: "dispositions", "hopes", "anticipations", "practical dominance of the surrounding space"; he also referred to the knowledge and evaluations of the subjects in relation to the functions that have been socially assigned to them and to the cultural reasonableness of their hopes, demands and actions.

The specific idea of male habitus would serve to "classify all things in the world and all practices according to distinctions which can be reduced to the opposition between male and female" ${ }^{\text {"4 }}$. It also includes the corporal hexis which are active in many spheres of social relations and also sexual relations, including foreplay and behavioral substitutes, some of which are not suspected of having a link to the above-mentioned habitus, being considered, therefore, deeply embedded.

Sexual scripting. This theory relates to the broader construct of social scripts, which was developed in the late 1960s by John Gagnon and other sociologists also who were aligned with the theatrical theoretical perspective ${ }^{5}$. Social scripts are constituted, basically, of expectations that social actors use to orient themselves in the situations they face on a daily basis, partially prescribing their performances. They equip individuals with guiding principles, but allow creative performances and improvisations when faced with the concrete situations being experienced. Thus, the individual experiences would be lived as if they were following pre-established scripts, although the final performance does not result from these scripts alone.

The sexual behaviors, related to the scripts available to individuals, should be seen as local phenomena, "with specific meanings and purposes in particular cultural-historical contexts," in the words of Gagnon ${ }^{5}$ that help to frame this research by the study of generations.

Male habitus and male sexual scripts. It is difficult to make a synthesis that reconciles the theoretical elements developed by Bourdieu and Gagnon due to the fact that the two authors did not cite each another in their respective works. in any event, habitus and scripts are both constructs about phenomena located in the interface between the individual (psyche and behavior) and the social, about which individuals and societies are usually unconscious, experiencing them as facticities. These constructs share the aim of explaining certain regularities of cognition and the behavior exercised socially.

The habitus correspond to potential cultural or sub-cultural potentialities and configurations which are responsible for the regularity observed in aspects of social life over time, becoming entangled with socio-psychological identities. Scripts, in turn, are more dynamic configurations and distinguishable from the representations and expectations that drive certain types of behavior in a more urgent manner. Although the scripts are not conscious, it is possible that individuals talk about and describe in detail their behavior or, metaphorically, about how they traveled, certain paths, even if they felt the path was new.

If we consider habitus and scripts pertaining to the same sphere of social phenomena (in this case, male habitus and male sexual scripts), the scripts would be situated within a more volatile sphere, of shorter duration, while the habitus would be closer to a stronger cultural nucleus with a higher resistance to changes. Among the various levels of scripting distinguished by Gagnon, the cultural level would be the one closest to habitus, due to its displaying a lower degree of mobility in relation to interpersonal and intra-psychic levels. 
Generation. In view of the increasing pluralization of patterns of behavior and interpretation of what is experienced in society (lifestyles), it seemed preferable to use one of the specific sociological meanings of the term generation, considering broader cultural phenomena than those restricted to family lineages. So we understand generation as a set of people born in the same period of time and who share, throughout their lives, approximately the same sequence of experiences $^{6}$. Such sets are sometimes marked by striking historical events, such as the advent of the AIDS epidemic in the 1980s, which, as explained below, "separated" the two generations studied.

Considering the above-mentioned concepts as the theoretical background for the empirical approach to the question posed, the specific objectives of the present study were:

a) analyze, in the accounts of the participants from the two generations, the similarities and asymmetries in conditioning, dispositions, behaviors and representations that are present in their mental and interpersonal sexual scripts, on the occasion of their respective sexual initiations;

b) Analyze cultural analogies and contrasts in the sexual initiation scripts of two generations or, in other words, generational markers corresponding to elements of the active male habitus;

c) Understand the possible meanings of these generational markers, in contrast to the continuities of the dispositions found, to what extent and in what way were they the result of two important historical and social contexts (the 70s and 90 s, pre- and post-AIDS) and to see whether it is possible despite eventual ruptures being discovered, to speak of hegemonic homologies of the male habitus;

d) Formulate hypotheses about how the asymmetries and homologies identified between the participants and the two generations related to their behavior in relation to health care in the field of sexuality.

\section{Methodology and procedures}

The methodology used was based on Thompson's delineation ${ }^{7}$ of the stages of empirical research for a hermeneutic perspective of the meanings expressed by participants in sociological and anthropological qualitative studies, which he called "depth hermeneutics"). This process starts with the ethnographic moment (capture of the hermeneutics of doxa) through, for example, as in this case, a collection of narratives and semi-structured interviews.
The post-ethnographic stages of the investigative process give it its true interpretative character. Based on the assumption that symbolic forms "do not exist in a vacuum," instead, on the contrary are "produced, transmitted and received in specific social and historical conditions" were attentive to the identification of the temporal-spatial situations in which production, circulation and reception of the cultural elements expressed occurred, as well as to the fields of interaction in which these exchanges occurred and to the backdrop of social structures and institutions (including the governmental institutions responsible for campaigns against STDs/AIDS that, in particular, we had postulated to have played a leading role). Regarding the social structure, we emphasized two aspects in our analysis of the reports: gender issues involved in sexual initiations and the social asymmetry of the participants (different levels of schooling of each of the sub-samples of two generations).

The discursive analysis of the reports was carried out by careful reading especially regarding the bipolarity of the representations and experiences of the participants in relation to health care $^{8}$, seeking to focus on their understanding and to make inferences about the psycho-cultural meanings of their having been sexually initiated and taken care of their health. Finally, we tried to achieve a synthesis of the hermeneutic process and interpret (or reinterpret) the data from the preceding analytical stages, projecting possible meanings or, in other words, arriving at an interpretive explanation of the participant's reports and, therefore, interpreting a territory already interpreted, in the words of Thompson.

\section{Data collection techniques}

The ethnographic moments (collection and capture of the hermeneutics of doxa) occurred in two studies that related to men in the city of Rio de Janeiro, both of which were coordinated by the second author of this text. The first study ("The construction of masculinity as an impediment to taking care of oneself" - undertaken between 2003 and 2005) involved adult men and aimed to understand aspects of the sociological imagination related to "being a man" that could potentially compromise their health. The second study ("Male sexuality and health care", undertaken between 2006 and 2008) proposed to analyze the significance attributed to sexuality and men's sexual health care by young men. Both studies used qualitative approaches and were undertaken with support from the National Coun- 
cil for Scientific and Technological Development (CNPq) and approved by the Committee for Research Ethics of the Fernandes Figueira National Institute for the Health of Women, Children and Adolescents, of the Oswaldo Cruz Foundation. In the present investigation, we used only the data collected in the above studies, not their analysis.

The samples from these studies were formulated considering a number of subjects that was sufficient to exhaust the number of meanings ${ }^{9}$ by including subjects successively in order to enable comprehensive theoretical discussions. In both cases, we used the sampling strategy known as "family universes"10,11 in which the researcher indicates people to participate in research who, in turn, indicate other participants.

Each of the two samples was composed of men who, due to being born in the same period of time, would have experienced common social events, thus making them part of the same generation ${ }^{6}$. From this point on in the article, such samples will be referred to as "young men" and "adult men".

The young men made up a cohort which was born approximately in the second half of the 1980s. They were aged between 18 and 25 years at the time they were interviewed and began their period of sexual initiation in the late 90s. This period was selected because it was during a period when there a large number of campaigns for the prevention of AIDS.

The generation of adult men was composed of men who were aged over 40 years at the time the reports were prepared, having experienced their period of sexual initiation in the 1970s, prior to the onset of the AIDS epidemic.

Each sample consisted of subgroups made up of different types of participants in socioeconomic and cultural terms. Among the young men, some of them were enrolled in higher education courses and others were not, living in a lower social class community (a so-called "favela"). Among the adult men, some had completed higher education and others had received less than four years of schooling. With this sample we intentionally made the assumption that the meanings attributed to male sexuality and sexual health care would differ according to the subgroups of different education levels and different socioeconomic classes.

As a result the study analyzed 60 reports of which 42 referred to young men and 18 to adult men. The heterogeneity in terms of schooling and socioeconomic class resulted in specificities for certain aspects of the reports. However, sev- eral homologies were also observed, as will be highlighted below.

\section{Results}

Chart 1 provides an outline of the main elements of the socio-historical contextual backdrops of the reports. Chart 2 presents and summarizes the analytical categorization structure that we used.

\section{The continuities and ruptures in mental scripts}

Chart 3 shows characteristics, continuities and ruptures of mental scripts based on the reports of the two sub-samples (adult men and young men), on the occasion of their sexual initiations.

\section{Reflexivities of the two generations regarding sexuality}

Among the young men, the scientific information on sexual health, distorted or not, seemed to have been incorporated into their social lives, some of them behaving as "spokesmen of common sense" in relation to "safe sex". While this had most certainly occurred in previous generations, it was assumed that there had been an increase in the scope and speed of the communication of scientific knowledge as from the 1990s.

Exposed, as they were from the beginning of their sexual lives, to the interpretations of other instances, such as to the AIDS prevention campaigns, the comments of the young men were imbued with reflexivity and assertion as regards their own sexual behavior. They commented on, in their view, the possibilities and personal choices they had faced. However, the preventive campaigns of the 1990s, because of having been implemented by socially recognized authorities (institutions of health and education), may have induced them to see as their own the ideas and representations of these government institutions. in any event, one of these "choices" related to the use of condoms: to use them or not, and how to use them.

Although some participants in higher education demonstrated a capacity for reflexivity, including the use of sociological concepts in their comments, in general the adult men found it difficult to exercise a hermeneutic view of what they had experienced, possible due to being alienated from the past (in Gagnon's words ${ }^{5}$ ) or lacking a link to the past processes that enable current cultural situations. They had the idea that previ- 
Chart 1. Analytical elements of the socio-historical context possibly affecting the process of sexual initiation (SI) of the participants (first post-ethnographic moment).

\begin{tabular}{|c|c|c|}
\hline Elements & Reports of the young men & Reports of the adult men \\
\hline $\begin{array}{l}\text { Temporal- } \\
\text { spacial } \\
\text { situations }\end{array}$ & $\begin{array}{l}\text { Situation with almost full potential for the use } \\
\text { of contraceptives } \\
\text { Massive exposure to erotic mass-market } \\
\text { cultural products (some explicitly sexual) } \\
\text { Gender relations (from the legal point } \\
\text { of view) guarantee of equal rights (e.g. } \\
\text { negotiation of the question of abortion with } \\
\text { partner) } \\
\text { AIDS epidemic and preventative discourses } \\
\text { present since childhood } \\
\text { Prevention practices (condom) encouraged } \\
\text { from the beginning of sex life }\end{array}$ & $\begin{array}{l}\text { Effective new contraceptive techniques (pill) } \\
\text { Sexual "liberation" increasingly present } \\
\text { Restriction of sexually explicit cultural } \\
\text { products } \\
\text { Increasing participation of women in the } \\
\text { labor market } \\
\text { Legal equality of gender relations and the } \\
\text { female's rights over her body } \\
\text { AIDS epidemic, preventative discourses } \\
\text { and practice of prevention (condoms) were } \\
\text { incorporated into a sex life already initiated }\end{array}$ \\
\hline $\begin{array}{c}\text { Fields of } \\
\text { interaction }\end{array}$ & $\begin{array}{l}\text { SI with friends and acquaintances, with } \\
\text { women of the same age, home and party (e.g. } \\
\text { dances) environments } \\
\text { Dyad of accessible women (for sex) and } \\
\text { inaccessible women (not for sex but to be } \\
\text { conquered for a stable relationship) } \\
\text { References to "others" (dissolute, lewd, } \\
\text { anomic, who do not care about "doing the } \\
\text { right thing", with protection using condoms) } \\
\text { Conversations with other men guided in part } \\
\text { by advice on healthy sexual practices (?) }\end{array}$ & $\begin{array}{l}\text { SI with older women (such relations seen as } \\
\text { opportunities to learn techniques), "furtive" } \\
\text { scenarios (alleys between buildings, inside the } \\
\text { car) } \\
\text { Dyad of accessible women (for sex "anybody", } \\
\text { "outsiders" - Mario) and inaccessible women } \\
\text { (for sex, "young girls"). Stability of future } \\
\text { relations guaranteed by institutions } \\
\text { References to "others" (with non-heterosexual } \\
\text { sexualities) } \\
\text { Other men give "meaning" to a behavior not } \\
\text { yet scripted } \\
\text { Friends perceived as inductors and instructors }\end{array}$ \\
\hline $\begin{array}{c}\text { Social } \\
\text { institutions }\end{array}$ & $\begin{array}{l}\text { Schools and community organizations } \\
\text { "sensitized" and committed to the issue of } \\
\text { prevention of STDs } \\
\text { Government campaigns directed especially at } \\
\text { this generation }\end{array}$ & $\begin{array}{l}\text { Stable "relations" guaranteed by institutions } \\
\text { and social structure (marriage) (as opposed } \\
\text { to sexual activity, the more laborious way to } \\
\text { gain access) }\end{array}$ \\
\hline $\begin{array}{c}\text { Social } \\
\text { structure }\end{array}$ & $\begin{array}{l}\text { Socio-economic heterogeneity and level of } \\
\text { education } \\
\text { Coexistence of a number of different groups } \\
\text { and cultural traditions (product of the } \\
\text { attraction, of the metropolis, for migrants and } \\
\text { immigrants) }\end{array}$ & $\begin{array}{l}\text { Socio-economic heterogeneity and level of } \\
\text { education }\end{array}$ \\
\hline
\end{tabular}

ously defined, behaviors, in which crucial choices were not believed to be possible, suggesting a status of further alienation from their sexualities, apparently thinking of them and living them as facticities, including resorting to fundamentalist religious ideas to explain them. Even though they had lived in the historical period of sexual "liberation" in the 60's and 70's, this was not the interpretation they had of their experiences, although one should consider the possibility that this was a case, in the words of Gagnon ${ }^{5}$, of a layer of memory which had been overcome, obscured and distorted by the social situations they had experienced in the following decades.

\section{A preconception of two types of partnership: fixed and not fixed}

With one exception, the participants of the two generations used heterosexual narratives, influenced by ideations of a dyadic typology of the 
women with whom they had had relations. This preconception, existing before the first sexual experience with another person, and analyzed in another text ${ }^{12}$, would have contributed to two different types of interpersonal scripts, commented on below, and, at the limit, to an expectation that the use of condoms after the establishment of a stable relationship was no longer necessary.

Young men's search for a stable relationship

The issue of orgasmic performance was not mentioned in the reports as being one of the practical motivations that drove young men's sexual scripts. The idea of "having to do it" (take the initiative, master sexual techniques) was present, but the practical reasons mentioned were of the type of achieving a "stable relationship".

The adult men also seemed attuned to the issue of stability, via "romantic love" or marriage. However, the generation of young males desired this type of love, treating it as a practical motivation ("you have to have feelings" - S).

\section{Exploration vs. sexual conquest}

In the two generations there is an emphasis on the "conquest" of the woman. Although, in general, they gave different connotations to this task (for the adult men, sexual conquest, for the young men, emotional conquest), both groups used the same warlike metaphor related to obtaining a partner.

For the young men, who perceived that there was a large "supply" of partners and easy access to them, sexual conquest was not seen as a problem. A frequent metaphor for exploration ("get" a woman) seemed indeed indicate a certain facility in having sex, although the ideal situation for them appeared to be monogamy, even if in a series of relationships. The personal approach seemed to be seen as an act aimed at another kind of possession, emotional. In their comments, the idea of taking the initiative for sexual advances was not absent, but there was a certain denaturalization of this behavior: although necessary, they did not consider it to be only expected from men.

For the generation of adult men, especially when the approach involved a woman they desired as "fixed", the idea of having the responsibility for sexual conquest initiatives was prevalent. Furthermore, this generation, according to the perspectives of the participants, faced a situation where it was difficult to access sexual partners, such that they targeted mainly sexual possession when approaching women.

\section{"Safe" sex for the two generations}

Both generations valued "safety" in their sex lives. However, there was a marked difference between them with respect to the information and knowledge seen as important for it.

Young people emphasized the know-how about their physical integrity, that is, to their health, especially in relation to AIDS, constituting what we call a pattern of "informed sexuality" in this generation ${ }^{13}$.

The generation of adult men emphasized the know-how which ensured another kind of integrity, that is, the integrity of their male identity. Considering that certain performances are expected of men, their sexual proto-scripts included the understanding of, and being well evaluated in, sexual techniques, aiming at a progressive accumulation of experiences that culminated in the mastering of the orgasmic cycle - their own and, largely, also that of their partners, such mastery being seen as a masculine role. 
Chart 3. Characteristics, continuities and ruptures of mental scripts based on the reports of the two sub-samples (adult men and young men), on the occasion of their sexual initiations.

\begin{tabular}{|c|c|c|}
\hline Generation of adult men & Generation of young men & Continuities and ruptures \\
\hline $\begin{array}{l}\text { Lower reflectivity, sexuality as a } \\
\text { facticity (a reality which is real } \\
\text { and natural) }\end{array}$ & $\begin{array}{l}\text { Greater reflexivity (scientific } \\
\text { information - distorted or not - } \\
\text { amalgamated with social lives, references } \\
\text { to the possibilities and choices) }\end{array}$ & $\begin{array}{l}\text { Rupture: } \\
\text { facticity } \rightarrow \text { reflexivity }\end{array}$ \\
\hline $\begin{array}{l}\text { Ideas of a dyadic typology of } \\
\text { women (fixed and not-fixed) }\end{array}$ & Idem & $\begin{array}{l}\text { Cognitive continuity of a } \\
\text { dyadic typology } \\
\text { (but corresponding to a } \\
\text { rupture in interpersonal scripts } \\
\text { in relation to the functions of } \\
\text { the two types of partners - see } \\
\text { Chart } 4 \text { ) }\end{array}$ \\
\hline $\begin{array}{l}\text { Fears, tensions, anxieties, } \\
\text { worries of not having a locus for } \\
\text { having sex }\end{array}$ & $\begin{array}{l}\text { Fears, tensions, anxieties, worries about } \\
\text { illness and premature death }\end{array}$ & $\begin{array}{l}\text { Affective continuity of painful } \\
\text { feelings regarding sexuality }\end{array}$ \\
\hline $\begin{array}{l}\text { Anxieties about sexual "safety": } \\
\text { the need for know-how that } \\
\text { will guarantee male identity } \\
\text { integrity }\end{array}$ & $\begin{array}{l}\text { Anxieties about sexual "safety": the } \\
\text { need for know-how that will guarantee } \\
\text { physical integrity }\end{array}$ & $\begin{array}{l}\text { Affective continuity of an } \\
\text { existential anxiety related to } \\
\text { sexuality } \\
\text { Cognitive rupture in terms of } \\
\text { "safety apparatus" required }\end{array}$ \\
\hline $\begin{array}{l}\text { "Trust" supported by the } \\
\text { institution of marriage }\end{array}$ & $\begin{array}{l}\text { "Trust" sought in direct relations with } \\
\text { the partner }\end{array}$ & $\begin{array}{l}\text { Continuity of "trust" as a } \\
\text { counterpoint to the anxieties } \\
\text { Rupture as to the origin of the } \\
\text { sense of "trust" }\end{array}$ \\
\hline- & Prospect of a long sex life & $\begin{array}{l}\text { Cognitive rupture regarding } \\
\text { the expectation of a sex life }\end{array}$ \\
\hline $\begin{array}{l}\text { Search for a stable partner } \\
\text { (marriage) }\end{array}$ & $\begin{array}{l}\text { Search for a stable partner (romantic } \\
\text { love in marriage or other types of fixed } \\
\text { relations) }\end{array}$ & $\begin{array}{l}\text { Volitional continuity desiring } \\
\text { a stable relationship }\end{array}$ \\
\hline $\begin{array}{l}\text { Perception of the sexual } \\
\text { conquest strategy as difficult }\end{array}$ & $\begin{array}{l}\text { Perception of the sexual conquest } \\
\text { strategy as easy }\end{array}$ & $\begin{array}{l}\text { Rupture in expectations } \\
\text { regarding sexual conquest }\end{array}$ \\
\hline
\end{tabular}

\section{Confidence vs. fear}

In addition to the cognitive elements of the above-mentioned mental scripts, there were others from the sphere of affectivity (fear, tension, anxiety, "worries" and concerns), a kind of backdrop for the reports of both the young men and the adult men. In the young men's narratives there was evidence of a certain fatalism, as if something very serious hovered over their sexuality ("I haven't caught anything yet [no disease], but suddenly I'm in line" - S, "It's a disease that kills slowly, something that will never have a cure "- R). Among the young men the phrases, "protect yourself" and "protect [the other]" were repeated frequently.

But the object of the young men's fears differed from that of the adult's. The younger men lived in fear of disease and premature death, seeing sexuality as a "modern day risk" 13,14 . The older men, on the other hand, expressed a fear of not finding a locus for sexual exercise, that is, the fear of not having how and with whom to perform it. 
For the adult men the fear of disease and death appeared as a new factor in their mental scripts.

The fears of the young men were probably due to the importance given to the strategies of "policing" and "constant attention" to "sex dangers", as well as the promotion of a feeling widely cited among them, trust. As a counterpoint to fear, "trust" would help in the separation of two distinct interpersonal scripts: "only sex" and "sex in a 'fixed relationship'", trust being the psychological key to pursue the "fixed relationship" being independent of the degree of objectivity in relation to the "fixedness" of the relationship (lasting, in the reports, from minutes to years). Trusting the woman appeared to be an indicator of the ideal relationship desired by young men: fixed, monogamous or "calm" (S).

\section{Prospects for sexual longevity}

The young men interviewed had the idea of an enduring sex life, relating this to a long life expectancy. "Health" would be a factor in ensuring it ("if you take care, you will go far" - S). Among the adult men, this idea appeared only indirectly, being included in their current mental sexual scripts.

\section{Concerning the continuities and ruptures in interpersonal scripts}

Characteristics, continuities and ruptures of interpersonal scripts based on the reports of the two sub-samples (adult men and young men), on the occasion of their sexual initiations (Chart 4).

\section{Use and non-use of condoms}

\section{in the two generations}

For the adult men, the condom (or other types of "care") was not mentioned when referring to the interpersonal scripts being followed in their sexual initiations. For the young men, on the contrary, the idea of care seemed to be embedded in day-to-day interpersonal scripts, although they were not necessarily linked to effective care practices from a scientific perspective.

To counter the prevalent idea of sex as something dangerous, one couple mentioned their rules: use condoms, choose "regular partners" and avoid "various partners that were not known." For others, the idea of routine care was associated with regular "preventive examina- tions", considering it to be a "mistake" to be more "relaxed" in this type of care.

Although they argued in favor of condoms based on "reason" and "knowledge" (as opposed to the "madness" of not using them - R), the motivations for their use was directed to different targets: besides the effects of contraception and the prevention of pathogen transmission, there was also the winning of the partner's trust and the perception of being aligned to the current socio-sexual order. Although introjected, these prescriptions generated moments of dissonance during the effective exercise of the interpersonal scripts: "It's tricky at the time to remember to use the condom, but you have to remember" (S).

For the generation of young men, the dyadic view of women seemed to contribute decisively to the choice between using condoms (with the "not fixed"), or not using them (with the "fixed"). For the adult men, this typology clearly determined the types of relationships that they had with women: with the "not fixed" ones they would learn to perform sexually, aiming to master the orgasmic cycle; with the "fixed" ones, they would play the role of emotional conquest, with their sexual performances already guaranteed by the "not fixed" ones.

\section{Biographical and "semiological" control over women}

The distinction between one type of sexual partner or another ("fixed" and "not fixed") 12 sometimes lead to the use of a kind of semiology that, although practiced without a clinical reason, seemed to be sufficient to denote states of health or disease to some of the young men. Their judgments about the risks were influenced mainly by visual observations and, at the limit, "beauty" was considered to be an indicator of health ("choosing based on her looks ... if she's ugly, you use a condom" - S).

At other times they seemed to exercise a "semiotic technique" even less practical than that under examination. One young man summarized the attribute being evaluated as the degree of self-care that women have ("you see that the person has a certain lack of care ...”- S). During the sexual act itself, one can undertake a "semiotic technique" based on a more objective and equally unsubstantiated empiricism, by examining the sexual organs of the partner. 
Chart 4. Characteristics, continuities and ruptures of interpersonal scripts based on the reports of the two subsamples (adult men and young men), on the occasion of their sexual initiations.

\begin{tabular}{|l|l|l|}
\hline \multicolumn{1}{|c|}{ Generation of adult men } & \multicolumn{1}{|c|}{ Generation of young men } & Continuities and ruptures \\
\hline $\begin{array}{l}\text { Practice sexual performance aiming } \\
\text { to master the orgasmic cycle (with } \\
\text { not-fixed partners). } \\
\begin{array}{l}\text { Following this, practice emotional } \\
\text { performance (with fixed partners) }\end{array}\end{array}$ & $\begin{array}{l}\text { Simultaneous practice of both } \\
\text { sexual performance (with not-fixed } \\
\text { and fixed partners) and emotional } \\
\text { performance (with fixed partners) }\end{array}$ & $\begin{array}{l}\text { Rupture of the sequence of } \\
\text { psychomotor performances } \\
\text { (sexual) and affective } \\
\text { (emotional): } \\
\text { sequentially } \rightarrow \text { simultaneously }\end{array}$ \\
\hline $\begin{array}{l}\text { Not using condoms during sexual } \\
\text { initiation }\end{array}$ & $\begin{array}{l}\text { Condom use as a possibility (tending } \\
\text { to be consistent with non-fixed } \\
\text { partners and inconsistent with a } \\
\text { fixed partner) }\end{array}$ & $\begin{array}{l}\text { Rupture of the style of } \\
\text { practicing penetration without } \\
\text { foreplay with not-fixed } \\
\text { partners } \\
\text { Continuity of the style of } \\
\text { practicing penetration without } \\
\text { foreplay with fixed partners }\end{array}$ \\
\hline $\begin{array}{l}\text { Difficult access to women (shortage } \\
\text { of "supply"): personal approach } \\
\text { targets sexual possession }\end{array}$ & $\begin{array}{l}\text { Easy access to women (large } \\
\text { "supply"): personal approach targets } \\
\text { emotional possession ("romantic } \\
\text { love") }\end{array}$ & $\begin{array}{l}\text { Rupture of the relation between } \\
\text { "supply" and "demand" for } \\
\text { sexual and emotional partners }\end{array}$ \\
\hline $\begin{array}{l}\text { Control of the woman assured by } \\
\text { the institutions }\end{array}$ & $\begin{array}{l}\text { Control of women by means of } \\
\text { a biographical evaluation and } \\
\text { semiotics to assess health and } \\
\text { character }\end{array}$ & $\begin{array}{l}\text { Continuity of a controlling } \\
\text { stance in relation to women }\end{array}$ \\
\hline
\end{tabular}

\section{Concerning the continuities and ruptures in interpersonal scripts}

Characteristics, continuities and ruptures of cultural scripts based on the reports of the two sub-samples (adult men and young men), on the occasion of their sexual initiations (Chart 5).

\section{The search for a non-conflicting sexuality}

One element apparently stable over the two generations, although manifested in different guises, was the desire to pursue a form of sexuality that did not come into conflict with the social circumstances in which the participants were embedded. Not entering into conflict, not adhering to an anomic sexuality, without rules, was reflected in an aspect of the participant's mental scripts, which was, to deal with the idea of chronic and constant sexual deprivation, in absolute terms or relative to that which they sought. Such deprivation would eventually be resolved if they followed certain scripts that, while effective (successful), were laborious and sometimes fruitless experiences. The idea that deprivation is a con- stituent part of being a man is something that was evidenced for the adult men, and seemed to persist in the generation of young men: bearing such hardships was perceived as a moral virtue: "because we must, as a man, as an individual, we must have our hardships" (S). Within this stoic attitude there seems to lie a cultural permanence between the two generations, an indication of a probable continuation of habitus.

\section{Reactions to "distortions" of the male socio-sexual order}

In addition to showing this resignation to deprivation, participants seem to react to what they assumed to be infractions or violations of the reigning socio-sexual order. However, there were some remarkable differences between the components of the two generations.

Among the older men, there were frequent demeaning references to non-heterosexual configurations. The young men, in their turn, often expressed moral judgments about the sex lives of other men, basing such judgments on the presence or absence of an attitude of caring for them- 


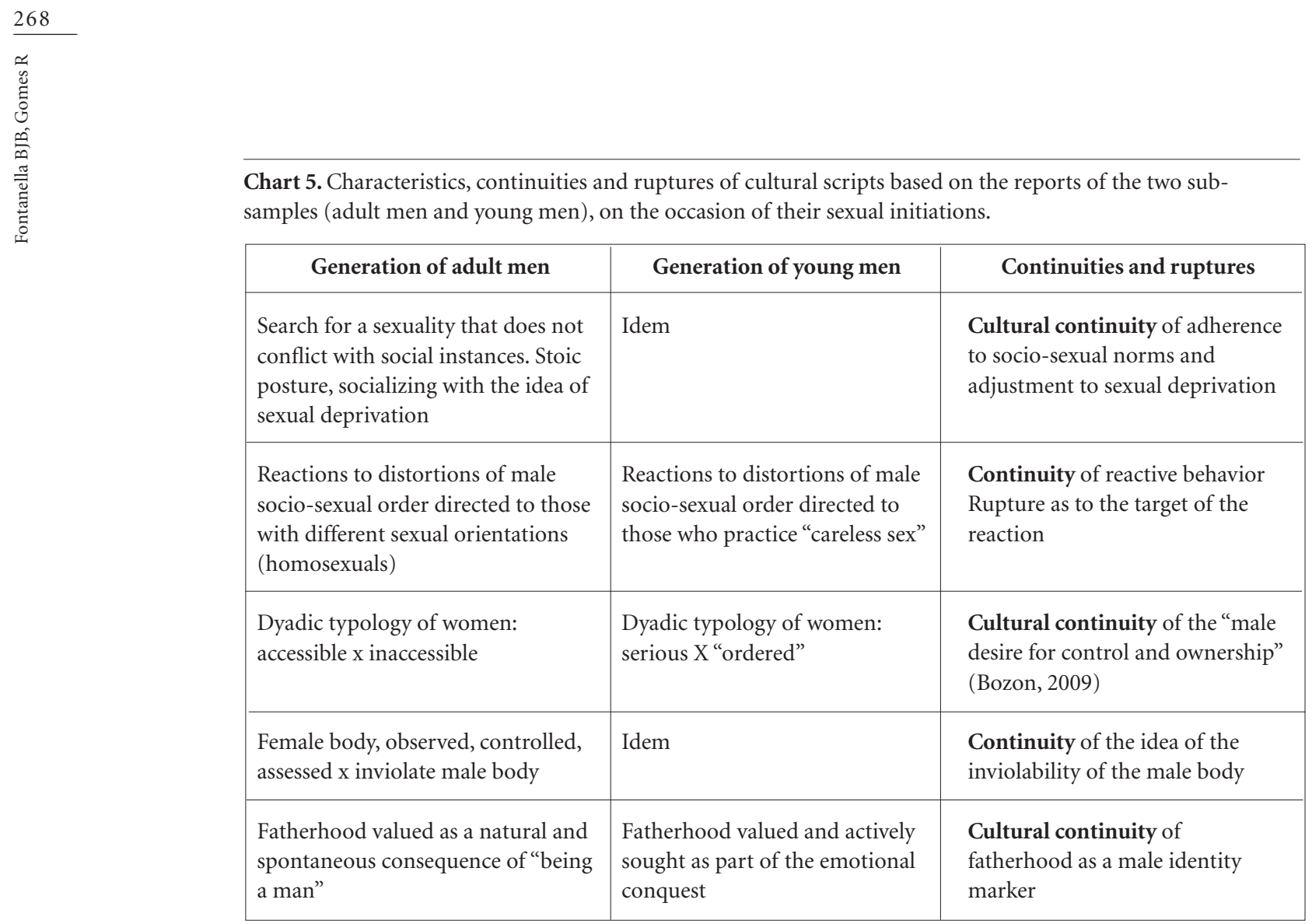

selves. These "others" lacked virtues in relation to AIDS prevention, and would be helpless when faced with the adaptive requirements represented by the disease. Other sexuality aspects of these "others" did not seem relevant for the young men, being considered personal ethical choices without any connotation of sexual offense or contempt for the social order; for example, sexual orientation, gender configuration and marital fidelity were not valued or demeaned.

Such critical ideational elements and, sometimes, also self-critical elements, seem to be based on a dichotomous notion of sexualities as "right" or "wrong," an apparent cultural constant between generations.

Dyadic typology and women's sexuality

Another cultural constant seemed to be the maintenance of a dyadic typology of women between the two generations. Members of both generations seemed to organize their interpersonal scripts according to this basic cognitive structure $^{12}$.

In relation to judgments made about the sexual life of women, questions of "moral accounting" surfaced ${ }^{5}$. The typology, which divided them basically into "accessible" and "inaccessible", persisted in the intra-psychic and cultural scripts of the two generations.

The geographical and biographical locus of these women (house or street; known or unknown biography), led to the recognition of indicators of virtue and "calmness" (S) in sexual activity: knowing a woman, her attitudes, would "guarantee" a man's security, physically and in terms of identity. This seemed to provide evidence that "man's desire for control and appropriation" 15 persisted, albeit clothed in different manners.

Another type of judgment about female sexuality associated "really liking sex" to something "unhealthy" or "disease" - terms that appeared only in the narratives of the adult men. Although there was the perception by both generations that it is female behavior that determines sexual opportunities, they did not expect initiatives or impulses by women, but only "dedication" to the relationship $(\mathrm{S})$.

\section{Inviolability of the male body}

In contrast to the idea that the female body should be constantly watched, controlled and even evaluated during sex for signs of trouble ${ }^{12}$, the participants from both generations gave indi- 
cations that they did not consider that the male body should be examined by his partner.

\section{Valuing fatherhood}

In the case of many of the young men participating, there was a clear trend of not caring too much about the possibility of a pregnancy resulting from sexual activity, when a fixed partnership had been established. This did not seem to worry them nor determine their attitudes in relation to the use or non-use of condoms. To want to "make a child" (R) was quoted as a practical motivation for some sexual relations.

In the case of the adult men, the question of paternity did not appear to be something important to achieve, but was seen more as a "natural" consequence of institutionally achievable fixed relationships.

\section{Discussion}

\section{Were there continuities and ruptures of habitus between the two generations?}

We hypothesized that some elements of the male habitus would remain stable over the two generations that were examined, sometimes varying only in how they presented themselves.

Among them, which attracted our attention, was the search for the exercise of sexuality without explicit conflicts in relation to social circumstances. This was apparently supported by a strong cultural base (to the point of not being verbalized, although it seemed to be in action at all times). Although the possible sources of conflict have changed over the decades (the prior socio-sexual order, heavily based on male identity security, later became, to a large extent, to be based also on the idea of physical security), the participants were seen to have scripts in both generations in strict conformity with these orders. Indicators of this were the hegemonic heterosexual scripts in the two generations and the comments which were strongly reactive to the distortion of socio-sexual orders, with the comments on prevention by the young men apparently being a variant of this.

Another striking element which persisted was the maintenance of the dyadic typology of women. Women were seen as historically "dangerous" beings for men ${ }^{16}$, and still needed to be "controlled". No longer institutionally, but in a more explicit way, based on certain individual practices (such as a biographical evaluation, a se- miology exercised on their bodies and the physical space still "reserved" for them - the home).

Another element that persisted was the prevalent idea that the male body was not intended to be examined or looked at by another person, such as a sexual partner or a health sector professional ${ }^{17}$.

On the other hand, an important rupture of an element of the male habitus seemed to be represented by the current tendency to develop, with the same women, in a simultaneous and parallel manner, an interpersonal sex script and an emotional script. For the generation of adult men interviewed, the development of both scripts tended to be sequential: initially the sexual script, in an attempt to fully develop the orgasmic cycle, and then the emotional script.

Although conquest (keeping the warlike metaphor) remained as an objective, the young men's emphasis seemed to be to pursue a strategy of achieving a more overall affective performance for the couple, while, for the generation of adult men, orgasmic performance was practically the only objective being sought. This can be explained, perhaps, by the existence of social institutions that hitherto had guaranteed the "conquest" of stability by marriage. The current overrating of parenthood by the young male participants may have been a consequence of this search for a more overall affective performance.

An inversion also seems to have occurred: for the generation of adult men, when in their youth, sex was something to be obtained, while the relationship was something that was guaranteed a priori by the institutions. For the young men, the opposite occurred: sex was guaranteed by social institutions (since some of its aspects were "taught" at school as well as by families and other institutions), while, on the other hand, the relationship needed to be conquered, with this aspect being highly valued in their comments. Such characteristics appeared to be revealed in this way as generational markers.

\section{Explanatory hypotheses for the ruptures and continuities}

The two generations studied were exposed to two characteristic moments when they became sexually active, even if one only considers the indicators designed by biomedical sciences for each of those periods. The generation of adult men had historically been the first one that could rely on effective contraceptive resources. The generation of young men, on the other hand, was ex- 
posed to a massive campaign to prevent STDs, as a result of the emergence of the AIDS epidemic in the 1980s. These generations were therefore exposed to certain cognitive elements that must have influenced the sexual scripts that were "available" to them socially. Gagnon had already stressed, in the $1960 \mathrm{~s}^{5}$, that among all social practices, sexual practices would be particularly subject, at the present time, to modifications arising from the knowledge obtained from scientific research, which was then transmuted into popular cultural knowledge. Although scientific and political bodies have concerned themselves with the day-to-day sexual life of people over the last two centuries, it was in the 1990s that they sought to exercise a massive and overwhelming influence.

Thus, the official campaigns on "safe sex" may have helped to shape, in a different way compared to the previous generation, the sexual scripts of the young men studied, especially as regards its most volatile dimensions (intra-psychic and interpersonal). One can equally assume that they had an effect on shaping not only the official large-scale initiatives, which aimed at, and still do, explicitly promoting changes, but also the various informal initiatives which reverberated, in everyday social life, the ideas developed in academic and political spheres.

Moreover the influence of other reifying universes, such as the theological or philosophical, had probably not changed very substantially over the two generations studied, such that they were less subjected to "discoveries", epidemiological turnarounds or political contingencies.

\section{Final comments}

A range of constraints, dispositions, behaviors and representations were identified in the three different dimensions of the sexual scripts experienced by the participants, during their sexual initiations. Simultaneous possibilities of intra-psychic sexual scripting were reported and they displayed, frequently, dissonances in relation to interpersonal and cultural scripts, not allowing one to speak of an immediate transposition from one to another.

By comparing the generations studied we inferred the existence of some continuities of the mentioned dispositions, possibly elements of the male habitus, which, by definition, are durable, although also transposable. Cultural factors which persisted in male sexuality, in the two different historical and social contexts that were the settings for the reported sexual scripts, were observed.

Further findings indicated differences or ruptures, dispositions that did not prove to be durable and which were not transposed to the subsequent generation. Such ruptures enabled the circumscription of possible generational markers or differentiated scripts for each generation.

A striking finding was an apparent inversion that occurred from one generation to the other: for the adult men, institutional guarantees were ascribed to stable relationships (marriage), whereas, for the generation of young men, such guarantees were ascribed to their sexual activities. Additionally, while for the adult men the beginning of sexual life represented an arduous task full of mishaps and difficulties, perhaps mainly aimed at ensuring their social identities as men, for the young men the greatest difficulties were to obtain guarantees of stable relationships, no longer guaranteed by marriage, and the constant fear for their physical integrity, that is, the fear of disease. Even if the analysis had been restricted only to the generation of young men, the observation of the two subgroups of different education levels would have been sufficient, in our view, to evidence the existence of considerable cultural diversity, despite them having similar ages and living in the same city.

The historical contexts experienced by the two generations appeared to have been factors in such generational markers. The AIDS epidemic and the educational activities of a preventive nature that followed, including the official campaigns to encourage "safe sex", seemed to comprise a terrifying backdrop for the scripts, a "modern day risk" which made it more difficult to make correct choices. Moreover, in the 1990s, "the information decade", when the young men had initiated their sexually activities, there was an high level of appreciation for these elements (information) as a basis for action. On the other hand, far from being immune to the terror represented by the AIDS epidemic, the generation of adult men found itself obliged to incorporate these new elements into the already well established scripts they were following.

Another apparent striking rupture occurred in relation to the simultaneity of the development of the sexual and emotional scripts for the young men, whereas, for the generation of adult men, it tended to occur in sequence: initially the mastering of sexual performance and later mastering the relationship. Some conflicts and unstable behavior in relation to condom use - always 
used in an inconsistent manner by the participants - seemed to be a result of the impulse to protect oneself and, at the same time, the urge to "trust" the partner that one desired to be "fixed" in a stable relationship.

On the other hand, we found continuities that persisted throughout the two generations, which possibly constituted hegemonic homologies of the male habitus. Some of them seem to repeat themselves in many generations, such as men's difficulties in relation to having their bodies examined - and the reverse: their conscious conviction that it is the female body that is "given" to be observed. Other apparent continuities related to the emphasis on the conquest of women and a dyadic typology of them, possibly a continuity which had existed over a long period of time and not merely during a few generations.

The ruptures and continuities found in the dispositions or the male habitus seemed to conform to the possible scripts available to the young men. Amid a wide range of possibilities, two major scripts seem to organize themselves: one of them with the "fixed" partner and the other with "non-fixed" partners, leading also to different behaviors in relation to the use of condoms and other measures of sexual health care.

\section{Collaborations}

veio outra tradução. O texto certo é este BJB Fontanella realizou a análise, a interpretação e a discussão dos resultados aqui abordados e redigiu o artigo. $\mathrm{R}$ Gomes elaborou o projeto de pesquisa, supervisionou a coleta de dados, participou da análise, da interpretação e da discussão dos resultados e da revisão final do artigo. 


\section{References}

1. Setton MGJ. A teoria do habitus em Pierre Bourdieu: uma leitura contemporânea. Rev Bras Educ 2002; 20: $60-70$.

2. Wacquant L. Habitus. In: Beckert J, Zafirovski M, editors. International Encyclopedia of Economic Sociology. London: Routledge; 2005. p. 315-319.

3. Bourdieu P. Meditações pascalianas. $2^{\mathrm{a}}$ ed. Rio de Janeiro: Bertrand Brasil; 2007.

4. Bourdieu P. A dominação masculina. $2^{\text {a }}$ ed. Rio de Janeiro: Bertrand Brasil; 2002.

5. Gagnon JH. Uma interpretação do desejo: ensaios sobreo estudo da sexualidade. Rio de Janeiro: Garamond; 2006.

6. Domingues JM. Gerações, modernidade e subjetividade coletiva. Tempo soc 2002; 14(1):67-89.

7. Thompson JB. Ideologia e cultura moderna: teoria social crítica dos meios de comunicação. Petrópolis: Vozes; 1990.

8. Gomes R, Mendonça EA. A representação e a experiência da doença: princípios para a pesquisa qualitativa em saúde. In: Minayo MCS, Deslandes S, organizadoras. Caminhos do pensamento: epistemologia e método. Rio de Janeiro: Editora Fiocruz; 2002. p. 109-132.

9. Minayo MCS. O desafio do conhecimento: pesquisa qualitativa em saúde. São Paulo: Hucitec; 2007.

10. Vaitsman J. Flexiveis e plurais: identidade, casamento e família em circunstâncias pós-modernas. Rio de Janeiro: Rocco; 1994.

11. Velho G. Individualismo e cultura. Rio de Janeiro: Zahar; 1981.

12. Fontanella BJB, Gomes R. Prevenção da AIDS no período de iniciação sexual: aspectos da dimensão simbólica da conduta de homens jovens. Cien Saude Coletiva 2012; 17(12):3311-3322.

13. Fontanella BJB, Gomes R. Novos roteiros intrapsíquicos versus permanências culturais: possíveis limites de uma sexualidade informada. Physis 2012; 22(3):11391158.

14. Beck U. Sociedade de risco: rumo a uma outra modernidade. São Paulo: Ed. 34; 2010.

15. Bozon M. Sociologie de la sexualité. $2^{\mathrm{a}}$ ed. Paris: Armand Colin; 2009.

16. Gay P. A experiência burguesa da Rainha Vitória a Freud: a educação dos sentidos. São Paulo: Companhia das Letras; 1988.

17. Gomes R, Nascimento EF, Rebello LEFS, Araújo FC. As arranhaduras da masculinidade: uma discussão sobre o toque retal como medida de prevenção do câncer prostático. Cien Saude Colet 2008; 13(6):1975-1984.

Article submitted 28/08/2013

Approved 27/10/2013

Final version submitted 29/10/2013 